\title{
Liturgical pharmacology: Time of the question, complexity and ethics
}

\begin{tabular}{|c|c|}
\hline \multicolumn{2}{|c|}{$\begin{array}{l}\text { Authors: } \\
\text { Calvyn C. du Toit }{ }^{1} \\
\text { Gys M. Loubser }\end{array}$} \\
\hline \multicolumn{2}{|c|}{$\begin{array}{l}\text { Affiliations: } \\
{ }^{1} \text { Department of Christian } \\
\text { Dogmatics and Ethics, Faculty } \\
\text { of Theology, University of } \\
\text { Pretoria, South Africa }\end{array}$} \\
\hline \multicolumn{2}{|c|}{$\begin{array}{l}\text { Description: } \\
\text { Dr M. Loubser is participating } \\
\text { in the research project of } \\
\text { Prof. Dr Danie Veldsman and } \\
\text { Dr C. Du Toit is participating } \\
\text { in the research project of } \\
\text { Dr. Willem Fourie, both of the } \\
\text { Department Dogmatics and } \\
\text { Christian Ethics, Faculty of } \\
\text { Theology, University of } \\
\text { Pretoria. }\end{array}$} \\
\hline \multicolumn{2}{|c|}{$\begin{array}{l}\text { Corresponding author: } \\
\text { Calvyn C. du Toit, } \\
\text { calvyn@outlook.com }\end{array}$} \\
\hline \multicolumn{2}{|c|}{$\begin{array}{l}\text { Received: } 08 \text { Oct. } 2015 \\
\text { Accepted: } 24 \text { Dec. } 2015 \\
\text { Published: } 31 \text { May } 2016\end{array}$} \\
\hline \multicolumn{2}{|c|}{$\begin{array}{l}\text { How to cite this article: } \\
\text { Du Toit, C.C. \& Loubser, G.M., } \\
\text { 2016, 'Liturgical } \\
\text { pharmacology: Time of the } \\
\text { question, complexity and } \\
\text { ethics', HTS Teologiese } \\
\text { Studies/Theological Studies } \\
\text { 72(1), a3214. http://dx.doi. } \\
\text { org/10.4102/hts.v72i1.3214 }\end{array}$} \\
\hline \multicolumn{2}{|c|}{$\begin{array}{l}\text { Copyright: } \\
\text { (c) 2016. The Authors. } \\
\text { Licensee: AOSIS. This worl } \\
\text { is licensed under the } \\
\text { Creative Commons } \\
\text { Attribution License. }\end{array}$} \\
\hline \multicolumn{2}{|l|}{ Read online: } \\
\hline 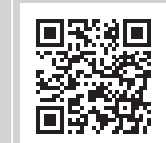 & $\begin{array}{l}\text { Scan this QR } \\
\text { code with your } \\
\text { smart phone or } \\
\text { mobile device } \\
\text { to read online. }\end{array}$ \\
\hline
\end{tabular}

Bernard Stiegler depicts technics as the human's tertiary memory retention generating a pharmakon with both curative and malignant potential. He additionally rues the posthuman epoch's depletion of a 'time of the question': revealed in the prevalent inaptitude for wisdom scilicet long-term acuity. We offer Christian liturgy as an abeyant psychotechnique arcing the current pharmakon to cure through soliciting a 'time of the question'. Rejuvenating Christian liturgy as a psychotechnique can bolster a broader societal 'time of the question'. Firstly, we describe technic's $d u$ jour mise on scène. Secondly, we constrain Christian liturgies as complex systems incorporating malleability, temporality, and instability. Thirdly, we imagine Christian liturgy as empty tradition allowing amateur repetition of ancient art enticing a time of the question'.

\section{Introduction}

Consider the contemporary technological mise on scène. The hysterical evolution of technics veers evermore towards short-circuited instant gratification, curtailing human propensity to adopt technical alterations ethically. Thus, brain-time and mind-space are commoditised, frenzied, and swamped. Brain-time and mind-space comments on both the axes of time and space: mind-space is a folk term for the more scholarly expression brain-time. Both terms denote the spatial-temporal limits of the human brain to process information, which when swamped results in, for example, heightened perceptual blindness.

Bulk psychosocial syncing, through crowd-sourced and mass-produced projected pictures, appears to be the only escape; as attention chopped into evermore hysterical nano-bursts; whilst being farmed for big data, chewed by obscured formulas and regurgitated as advertisements purporting to cater to every unique profile. Moreover, one is concurrently observed, voluntarily or involuntarily, through the self-same devices enabling access to seemingly ethereal, hysterical, and culturally commoditised worlds. In other words, as data farming, surveying and selling machines, attentive and attention grabbing mobile devices, simultaneously promote hyper-attention and hyper-distraction. Hyper-attention is needed for farming big data and surveillance, whilst hyper-distraction ensues from ever-new offerings pushed towards the user.

The constant-instant time (Virilio 2007:83-101) of the current technics' inscription, however, flattens the possibilities of producing a shared organology not to mention the long-term attention formation practices needed for ethics. Hence, extremes reign: from pundits who pander to digital singularity (an immersion in the noosphere), ${ }^{1}$ to pessimists who plea for a return to a past naively imagined as more authentic. Herein, enters James Smith's idea that liturgies culturally structure human desire with such promise and yet, one suspects, lacks in its analysis the scope to deal with this new technical epoch.

Smith's (2009:72) prowess is an account of culture as liturgical education, structuring and ethically colouring human desire, yet this interpretation remains wanting in the emerging technical epoch. However, Smith's analysis of how cultural liturgies structure human desire handles spatial slowmoving systems (like malls) well, whereas the present venture asks for the modelling of emergent, illusive, non-linear liturgical systems in the developing technical epoch. As the next section will explain, the increased speed of technics - vacillating between hyper-attention and hyperdistraction - desists human otium time: the time texture which facilitates the formation of stable cultural liturgies.

1.Noosphere was Pierre Teilhard de Chardin's term for a complex connected consciousness sustaining accord (Galleni 2011:72-76; Spadaro 2014:97-100). Digital gurus adopted noosphere to denote the internet (urbs) and World Wide Web's (civitas) complexity and connectivity veering, according to some, to digital singularity (Lanier 2010:45). 
For this reason, Bernard Stiegler's description of technics producing a pharmakon, and Paul Cilliers's illumination of complexity, should augment Smith's evaluations: putting Christian liturgy within a broader network of meaning, as a spiritual system of consistency, potentially provoking a 'time of the question'. Such a framing would redeploy Christian liturgy's potential to contribute to a broader societal discussion on ethics, rather than ceding it into church-ghettos.

Three sections discuss the recommended augmentation of Smith's cultural liturgies structuring desire. Firstly, the paper describes technics as tertiary memory retention, the pharmacology generated by technics, and the current symbolic misery of society. Secondly, Christian liturgy is chalked as complex, rather than complicated, incorporating transversality, temporality, and non-linear creativity, whilst not neglecting structure, Christian tradition, and embodiment. Thirdly, the study considers Christian liturgy as an amateur repetition of ancient art possibly enticing a 'time of the question'.

\section{Technics as tertiary memory retention}

Technics should not be conflated with post-industrial revolution technology. Lewis (2013:53) expounds technics in brief:

\begin{abstract}
'Technics' is an obsolete English word that is used to translate a modern French term which encompasses techniques, technology, and the objects produced by these means: it thus includes the objects of pre-modern craft, pre-industrial and industrial techniques, and modern machine-powered technology.
\end{abstract}

The memory retained in technics, Stiegler (2013:72) asserts, is the externalised prosthetic constituting and sustaining humanity.

Here, Ross (2013:248) gives an excellent summary of primary, secondary, and tertiary memory as understood by Stiegler.

[T]hree great epochs of memory must be distinguished:

- that of generic conservation, the persistence-in-becoming of the DNA molecule that has enabled the great terrestrial process of vital individuation;

- that of nervous memory, the capacity of animals possessing nervous systems to finitely retain, and to have their behavioural programs altered by, the events of their own experience;

- that of technical memory, the inscription of form in inanimate matter by beings whose cortical evolution is then affected by this capacity and the specular capacity to 'return' to these technical objects, which then also function as a projection screen and contribute to the formation of a non-biological process of becoming including the formation of socio-ethic programs, idiomatic differences, technical inventions, and all the others of physis, the pursuit of life by means other than life (TT1, 17/31) [Stiegler 1998], amounting to what, following Simondon, Stiegler calls processes of psychic, collective and technical individuation.
For Stiegler (2015:75), then, a hammer is as much a technical object, as is say, a word. Both are externalised forms retaining memory. Even when the original producer is removed, this externalised memory remains part of the public domain or public reason. Words, hammers, wheels, fire, and other technical objects, once structured and externalised, can now be rearranged by others into new structures unintended by its original producer. As such, this public domain or public reason constitutes what analytical philosophers call cultural memory: which are conserved ideas through various cultural liturgies, one might say. Although Smith acknowledges cultural liturgies, the problem today is how current technics in the public domain and of the public reason have become psycho-frantic, swamping brain-time with negotium, being a constant working as product. What is needed is an understanding of how to reinvigorate the otium of a 'time of the question'.

In brief, then, technics covers every artefact aiding human memory through externalisation: tools, art, fibre optics, writing, aircraft, and others. These technical objects also have a spiritual texture always egressing the material object, as a hauntology (Derrida 1994:10, 63, 202): the amalgamated (re) memory of the preceding generations' production, unseen to those who adopt and adapt them.

\section{Here is Stiegler's (2014b) articulation of this:}

There is something that supports spirit, and this thing is material, contingent and instrumental. The instruments of spirit are no doubt insufficient to yield spirit: they are dead. Now, spirit only exists in one of the living. But it is only in one of the living as what had been living, but no longer does. It is only one of the living as a trace of the fragility of life - and, too, of spirit itself, of which one must therefore take care (in Greek, therapeuma). And yet, there is a life of spirit; and such a life is profoundly marked by technicity ... (pp. 84-86)

Consequently, tertiary memory retention includes psychosyncing technics: stock exchanges, syllabuses and, yes, even university administration. The hindmost example allows one to see how psychosyncing technics have the fabric of a pharmakon, promising both the possibility of health and harm.

Indeed, if one understands technics as pharmacological, containing both healing or harming potential, the current realities pleads for therapeutic systems, like Christian liturgy, to counter the potential harming effect of technics whilst nuancing its healing potentials. Stiegler (2010) explains why such therapeutic systems are important:

For every stage of grammatization, societies institute therapeutic systems, systems of care, techniques of self and others, which constitute spiritualities and diverse noetic forms, from the shamanistic models to artistic models, passing through churches, medical therapies, schools, sports, philosophies, and every system of sublimation. These systems, which are concrete expressions of the tendency to cultivate consistences, nevertheless presuppose the apparatus of production of subsistences with which they compose, and through which is formed a negotium which, as commerce, is also a calculation about what does exist and what will exist. What composes together, then, is the otium of 
consistences, the negotium of subsistences and that which constitutes existences worthy of this name - through which a savoir-vivre is formed that one can call existence. (pp. 120-121)

Therapeutic systems, thus, produce a savoir-vivre [goodmanners] from technics' pharmacological texture. Furthermore, savoir-vivre can only be produced where a shared symbolic background, or organology, consists through attention training. Christian liturgy is one such attention training device to develop humans towards maturity: from dependence towards responsibility for and towards broader society; from the inability to imagine or promise any future to the consistency of promising the future - what Stiegler (2010:54-57, 72-74) calls ethics.

Considering the context sketched by the introduction, no wonder Stiegler mourns the developing technical epoch's symbolic misery: '... [a] situation in which $\ldots$ aesthetic experience has been replaced by conditioning, producing alienation and anomie on a massive scale' (Crowley 2013:119). Similarly Lanier (2010), a pioneer of Virtual Reality, notes:

When developers of digital technologies design a program that requires you to interact with a computer as if it were a person, they ask you to accept in some corner of your brain that you might also be conceived of as a program ... (p. 4)

Indeed, such symbolic misery conversed with Christian liturgy baits a dimensional augmentation of Smith's cultural liturgies structuring desire.

Before considering Smith's cultural liturgies' structuring desire, a further note on how this symbolic misery functions is provided. Symbolic misery results from an otium-deficiency. The sublimated negotium practices flooding brain-time and mind-space described in the introduction, and it pulls apart the consistence of being human with and through other humans. In other words, negotium infiltrates and poses as otuim and, in turn, allows no 'time of the question' needed to pull oneself together.

One could argue that late market capitalism has always paraded negotium as otium, but with the current rapidity of technic change the texture of this onslaught has transformed space-time into brain-time. It is precisely the result of this new infiltration of negotium, even into the otium of brain-time, that Smith's cultural liturgies structuring desire needs augmentation. Liturgies, then, are no longer sealed compartments of learning in space as Smith assumes.

For this reason, Smith's cultural liturgies structuring desire is unable to model the concurrent hyper-attention and hyper-distraction, flooding mind-space and brain-time. Put differently, and improvising on a metaphor Smith uses: the mall no longer facilitates the capitalist liturgy, as Smith (2009:19-22) thinks. The mall and other liturgies are now swamping human mind-space and not architectonic space. Where previous cultural liturgies structuring desire overwhelmed space external to humans, now new psychosyncing devices have infiltrated the mind-space's otium, scattering desire by educating available brain-time to vacillate rapidly between hyper-attention and hyper-distraction.

Reconstituting the attention needed to illicit the healing texture from current technics is a broader societal problem. In Taking Care of Youth and the Generations Stiegler (2010:102) relates the importance of psychotechnique or psychotechnology for attention forming practices:

... [A]ttention is always not only assisted but in fact formed by a psychotechnique or a psychotechnology. But through addressing the question of care as a mature form of attention, I am suggesting that a system of care that augments attention is what persistently guards against the pharmakon's efforts to destroy the attention constructed precisely as care - as therapeutics. Yet in this regard, from the 'therapeutic' point of view, computational psychotechnology always aims at substituting for attention, theorizing and modeling attention and its institutions, destroying them by seeming not even to imagine an attention beyond vigilance, let alone that this attention is consciousness constructing its objects.

So, if homo technicus predates homo liturgicus by utilising the tertiary memory of technics such as writing, electricity and architecture to enable liturgy, the question for contemplating liturgy becomes: How might technical objects be arranged, through and in ritual, to elicit the new pharmakon's care? Here, liturgy joins other psychotechniques which might produce reflective consistency through a particular arrangement of technical objects oozing externalised memory (Stiegler 2014a:41). Complexity's assistance is, furthermore, needed to postulate how Christian liturgy might aid in producing broader societal meaning, wisdom, and ethics (promising the future) from such hysterical development, which diminishes the human disposition to attention and care.

\section{The dynamics of complex liturgies}

Christian liturgy, chalked as complex rather than complicated, incorporates transversality, temporality, and non-linear creativity, whilst not neglecting structure, Christian tradition, and embodiment. Such open systems also clear-up Smith's seemingly arbitrary assignment of thin and thick rituals.

Initially, Smith's distinction between thin and thick rituals seems clear. The thickness or thinness of ritual is relative to its teleology (Smith 2009:82-83). Yet, Smith slips into the problem of describing rituals as means driving towards ends. Smith's (2009:86) first mistake is to frame brushing teeth as a thin ritual: a ritual one cannot understand without the medical-media industrial complex forming social ideas about health and beauty.

Next, Smith (2009:88) claims that some rituals that seem thin are indeed thick. Here Smith's lack of a rigorous systemic theory of meaning begins to show. The problem is twofold. Firstly, Smith faces the challenge: what are the criteria for a ritual to be thin and thick. Thus, he misses the obvious: the potential thick ritual of brushing teeth remains, for him, resolutely thin. Furthermore, his reading opens the possibility that any thin ritual can suddenly become thick for no reason. 
Now, the second question Smith must answer becomes clear. If some thin rituals are actually thick and others thin, who shall peer through the misty cloud to illuminate the true thick rituals? Whomever, of course, is the powerful deciding master. Smith has thus committed the anthropological faux pas already debunked by Miner's (1956) seminal article Body Ritual among the Nacirema: Smith wants to play insider and outsider, the Lacanian Master and Analyst, at the same time.

We suggest that rituals can be described as thick or thin in relation to their wider liturgies. Furthermore, liturgies, economic or religious, do not function in isolation, but interpenetrate, and exert an effect on, each other. Liturgies are complex systems which shape, and are shaped by, their environments. Cilliers (2005:257) offers twelve characteristics of complex systems. This essay draws on three of these to describe the dynamics of liturgies as psychotechnique. We argue that liturgies are open, have histories, and are in disequilibrium.

\section{The malleability of liturgies}

Liturgies are open systems, meaning they are influenced by both their internal and external technics (cf. Cilliers 1998:122). This permeability can be seen in the way Gutenburg's press (an extrinsic technic) influenced the Reformation (cf. Füssel 2005:159-195). However, openness to external technics does not mean liturgies mirror their external technics, rather liturgies relate to, for example: cultural, political, and electronic technics. It is exactly these relationships that implore us to offer provisional descriptions of liturgies because liturgies undergo constant change. Participants never participate in the same liturgy twice because both liturgies and their participants change.

Participants have a responsibility toward liturgies, because, by participating, they effect internal psychosyncing. Music, for instance, is a cultural psychosyncing technic wielding extraordinary influence on the formation of cultural identities through liturgies. Consider the various liturgical inscriptions of music during the Reformation. Luther, a great admirer of Josquin de Prés, continued a tradition of borrowing secular melodies; Zwingli, famously forbade music; whilst Calvin considered Psalms key texts for congregational singing. Contemporary worship music has had a similar influence on forming cultural identities through liturgies (cf. Ingalls 2008:52-258). The question remains how to integrate such eternal psychotechniques responsibly.

\section{The temporality of liturgies}

Liturgies also have histories (cf. Cilliers 1998:122). These histories develop through an accumulation of relevant technics, which gear liturgies to engage altering technics in their atmospheres (cf. Cilliers 2007:54-55). Liturgies engage such innovations by drawing on their histories to anticipate possible futures. When contrived - continually breaking with their histories - liturgies labour at reacting to transitions in their technical milieu; hyper-amnesia which leads to fragmented hyperactive liturgical identity (cf. Cilliers 2007:57). The same holds for liturgies incessantly swapping possible futures apathetic to their history or character. Such liturgies inevitably and imprudently adopt the fashion $d u$ jour.

The history of liturgies are distributed through their technics (cf. Cilliers 1998:108) whose arrangements are actively formed via sui generis selection processes (cf. Cilliers 2007:58). The distributed nature of these histories also means motley arrangements of such technics (cf. Cilliers 1998:122). However, one should heed the arrangement of technics as a choice supporting liturgical identity development (cf. Cilliers 2007:58). For example, Reformed confessions can be regarded as a snapshot of a psychosyncing technique framed during a specific period, that still partly shape Reformed liturgies today. The continued functioning of these technics in liturgies is a matter of decision and reflection - not a matter of stunting liturgies (cf. Cilliers 1998:108).

When new technics emerge one must guard against expediting ontogenesis, which abandons reflection and may result in psychotechniques not characterised by care but by idiocy: psychosocial syncing through advertising or mere entertainment (Goriunova 2012:223-235; Stiegler 2010:30-35). Liturgies coalesce fastidiously because 'more varied, richer, deeper and better integrated memory will open up more sophisticated anticipatory capabilities' (Cilliers 2007:58). To retain liturgical identities certain internal psychotechniques evolve sluggishly compared to other internalised technics. Paul Cilliers (2007) writes:

Slowness is in itself a temporal notion, and in many ways the opposite of the notion 'static'. In point of fact, it is actually an unreflective fastness, which always returns you to the same place. (p. 54)

Liturgies decipher extraneous and intramural technics, discerning utile and inutile information through their identities (cf. Cilliers 2007:58). Liturgies lag behind orbital technical hysterics. Such hysteresis helps liturgies preserve the required coherence to retain consistence amidst fluctuations in technological epochs. Merely mimicking orbital technics would evaporate a liturgical identity. Drawing on memory, however, liturgies may select and arrange orbiting technics and produce a psychotechnique which forms individuals to promise the future and, hence, ethics.

A slightly slower tempo allows liturgies to foster richer and more thoughtful psychotechniques and, accordingly, results in liturgies that sustainably negotiate surprises in their external and internal technics (cf. Cilliers 2007:59). Moreover, experience alone, such as identity, can illuminate an apt tempo of change (cf. Cilliers 2007:59). This means the dynamics of each liturgy ought to be appraised and described independently. Hence, fastidiously following templates decimates the potential diversity each local psychotechnique may contribute in our changing technical epoch.

Here, Edgar Morin's distinction between restricted complexity and general complexity becomes paramount. Restricted 
complexity simplifies: creating laws and universal axioms for evaluating and defining all liturgies (Human \& Cilliers 2013:31). In other words, singular truth is applied, perforce, to all liturgies: such as desire or worship (cf. Morin 2007:28). However, an interest in the interrelation of liturgies and technics, rather than in truisms, means drawing on general complexity (Human \& Cilliers 2013:32).

\section{The instability of liturgies}

In terms of complexity, liturgies operate under conditions far from equilibrium (Cilliers 1998:122). Liturgies constantly engage other psychotechniques of culture, politics, and economics. This disequilibrium is prompted by intermural and external difference. One may, to some degree, quickly distinguish liturgies from their orbital psychotechniques, but then one risks neglecting internal liturgical difference. A rich and nuanced identity evolves through meaningful relationships between diverse internal technics (Cilliers 2010:61). However, diversity does not imply an open and vague identity that tries to be everything for everybody. A lush identity is also richly constrained, that is, specific and nuanced (Cilliers 2010:61).

The way in which perimeters are described constitutes liturgies. Liturgies that solidify their boundaries, solely recycling internal technics and well-established difference, may steadily develop lean and static identities (cf. Cilliers 2010:61). Fecund interplay with exterior desire-shaping psychotechniques intensifies a liturgy's rich and resilient identity (cf. Cilliers 2010). Yet, how does one discern a particular liturgy from another, without falling into the same trap as Smith?

A liturgies' ambit cannot be altogether described through object, language, and method of worship (cf. Van Huyssteen 1997:16). One should consider the foci of liturgies, the experiential scope and heuristic devises that participants employ. The experiential scope indicates the experiences and phenomena participants appeal to when justifying their participation. Participants from different liturgies may find facets of their focus to be imbricate, but the experiential scope of their liturgies differ (cf. Van Huyssteen 1999:187). For example, a reformed Christian and a catholic Christian may find that aspects of their focus overlap, but their experiential scope will differ.

Smith (2009:19-22) rightly represents economic behaviour (the mall) as liturgical, however, curiously he describes such secular liturgies as isolated from others. In practice, participants partake in multiple liturgies at once (du Toit 2014:245-246). We suggest that focus, experiential scope, and heuristic devices offer participants ways to describe liturgical boundaries. This is paramount because liturgies as being interpenetrable (cf. Cilliers \& Nicolescu 2012:716) implies that participants can draw on the experiential scope and heuristic structures to demarcate liturgies.

As liturgies respond to transitioning technics, in their atmosphere, they themselves change (cf. Cilliers 1998:108) and as liturgical identities evolve so also do their ethics. The forming activities (ethics) of liturgies are not ossified but malleable. Although such alteration may be slow, as liturgies change, their ethics change and their participants are formed differently (cf. Cilliers 2010:57). Every description of liturgy is provisional; one can also only evaluate their actions provisionally; and, therefore, thinking of ethics as stringent and universal laws remains impossible. Each liturgy has a unique identity engendered by a particular contextual arrangement of technics which sculpt local ethics: for example, an urban ethic differs from a rural ethic. Liturgies are also not merely an arrangement of available technics, but they can prepare for potential changes in their orbital technics through developing surplus (excess) diversity.

Liturgies have a requisite diversity which is the nadir of diversity needed to function. Surplus diversity is more than this. Liturgies can develop surplus (excess) diversity for engaging orbital technics through internal experimentation. This guards against a neurotic naturalisation of orbital technics (cf. Woermann \& Cilliers 2012:408) because:

Excess diversity in the system allows the system to cope with novel features in the environment without losing its identity - as long as one remembers that identity is now a dynamic concept which is subject to change. What is more, if a system has more diversity than it needs in order to merely cope with its environment, it can experiment internally with alternative possibilities. (pp. 413-414)

When liturgies have an excess diversity of technics their viability, resilience, and sustainability increases through internal experimentation (cf. Woerman \& Cilliers 2012:414).

Surplus diversity occurs when internal experimentation generates several strategies for operating in possible futures. In other words, liturgies depend on their surplus diversity for long-term survival (cf. Woerman \& Cilliers 2012:414). This creative and imaginative action should not be understood as flights of fancy, but as a careful and responsible development of surplus diversity (Cilliers 2005:264). The identity of liturgies can become static, by ignoring important changes in external technics and by not interacting with or by ignoring other cultural liturgies or psychotechniques (cf. Cilliers 2010:61). To fix relationships in liturgies and close the boundaries of liturgies rigidity is introduced, leading to social pathology. When this happens, liturgies, as psychotechnique, no longer heal their participants, but poison them.

\section{Christian liturgy as ancient art producing a 'time of the question'}

The current technical epoch read through Stiegler's portrayal of technics, which produces a pharmakon and Cilliers's complexity, allows one to appreciate the limits of the structuring desire of Smith's cultural liturgies. Smith seems rigid about the boundaries between cultural liturgies whilst arbitrarily assigning thin and thick meaning to rituals. Stiegler's technics, which produce a pharmakon, and Cilliers's description of complexity, however, nuance Smith's view by 
sketching all technical memory as potentially transversing cultural liturgies. The pharmakon of a shopping mall, just as Christian liturgy, has both a curative and destructive potential, disseminated non-linearly throughout various cultural liturgies - an irony in no small way lost on Victor Gruen, the creator of the modern shopping mall (Gladwell 2004). ${ }^{2}$

In Victor Hugo's classic Notre Dame de Paris, the Notre Dame cathedral also grows into a character. In the second chapter of book five, Hugo (2011:137) wrote the oft cited: Ceci tuera cela. Le livre tuera l'édifice [This will kill that. The book will kill the building]. Here, Hugo refers to the technic of printing supplanting the technic of architecture: the tragedy of one technical epoch usurping another. After German Rococo, as Harries (1983) postulated, symbolic meaning in architecture deteriorated, or one should rather say, there was a loss of communal agreement on what architectonic symbols meant.

For years, the Notre Dame and other cathedrals acted as memory nodes reminding city denizens and strangers of the memory residing in all infrastructure (Du Toit 2015:12-13). Lay people read symbols on the cathedral's west-work, for instance, and reconstitute themselves with the living and through the dead. As psychotechnique, the cathedral facade facilitated the otium of questioning one's relation to a common organology. As such, cathedrals elicited the healing capacities of the pharmakon produced by the architectonic technical epoch, allowing denizens time for otium.

Then, as printing slowly replaced the cohesion of the cathedral, governments later implemented public school systems as otium for the youth. Hence, public schools taught young people how to attend, contour, and cohere printed information, produced at a bulk and speed never before seen. As pointed out in a previous section, this technical epochal change to printed text also impacted Christian liturgies. Yet, Hugo's words should echo again today, as humanity moves from the machine-age printing press into the light-age touch screen where everything always already arrives (Virilio 2005:120-135). Ceci tuera cela.

The newly emerging technical epoch delivers information at an even higher speed and volume. Under such circumstances, the weekly viewing of art, or the close reading of a printed text, seems like observing nostalgic Romantic ruins. Now, mind-space is a permanent outpost of hyper-attention and hyper-distraction machines destroying otium. Moreover, the challenge of the emerging technical epoch is not only to structure desire, but how desire is frenzied, scattered, and destroyed in occupied brain-time (Stiegler 2010:38, 196, 202) through the superego's injunction to enjoy (Žižek \& Gunjević 2012:22).

Reinvigorating a 'time of the question', in the current emerging technical epoch, is challenging because the current

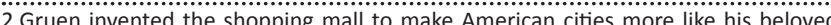
Vienna, yet this pharmakon veered towards economic exploitation. When returning to Vienna, disappointed a what his creation had becomploitan. When returning to Vrend , disappointed at whell (2004) puts it: 'Victor Gruen inverted the shopping a brand new mall. As Gladwell (2004) puts it: 'Victor Gruen invented the shopping mall in order to make America more like Vienna. He ended up making Vienna more like America' persuasive psychotechnics of mass-hypnotic hysteria co-opt attention and time-awareness (Stiegler 2013:51-52). Here, however, the ancient contemplative art of Christian liturgy can make a notable contribution. Christian liturgy, as attention forming psychotechnique, however, can only act as otium eliciting a 'time of the question' if the very technics producing concurrent hyper-distraction and hyper-attention can be spliced into its rich memory. A note on Christian liturgy as public event must be made, before suggesting two possibilities for eliciting the caring aspect of the pharmakon of the current technical epoch, through Christian liturgy, as repletion of ancient art.

There is much talk about Christian liturgies as public event. In previous technic epochs, architectonic or printed space always developed externalised structures for incubating the healing effect of its produced pharmakon. Today, however, space is shattered, sublimated, and scattered into occupying brain-time and mind-space that swamps desire. The challenge, today, is not public space but attention.

Christian liturgy, as a public event, could easily turn into public spectacle, a carnival, or a 'selfie' opportunity, adding to new media idiocy. What is needed, rather, is a thoughtful, even prayerful, integration of new technics into Christian liturgy. This means assimilating technics into the attention forming practice of Christian liturgy, rather than contributing to the frenzy of public spectacle that is rife today.

If public scepticism is chosen, Christian liturgies risk contributing to humanity's proletarianisation by machines, mining for big data, that increase perceptual blindness through distraction, consequently, producing a lack in the long-term thinking needed for ethics. The question is, thus, not: How does one reinvigorate the public character of Christian liturgy? But rather: How does one choose to integrate the current shift in technical epoch for ethical longterm thinking through liturgy?

Such careful, and indeed prayerful, integration of technics into Christian liturgical memory would introduce an otium break into hyper-distraction and hyper-attention. One can only promise the future, which is to live ethically, once technics are loved into memory through cultural liturgy. As Versfeld (2004) may have put it: To love, to take care (of the future), to live ethically, one must (ironically) wait. Only waiters love (the future), take time for questioning, releasing desire from swamped brain-time to question the pharmakon, generated by the current technical epoch, into a healing texture.

Now, bearing the problems of liturgy as public act in mind, one can return to liturgical practice with the question: How might Christian liturgy activate a 'time of the question' in the emerging technical epoch? Two suggestions come distilled from the present paper. Firstly, one could, for example, add a daily or weekly prayer to a Christian liturgy thanking the Triune God for the gift of technics whilst imploring 
participants to use such things wisely. Here is a possible prayer:

Father, Son, and Holy Spirit, we thank you for the gift of technology, for writing, electricity, mobile devices, markets, and all other technics making life humane for so many. Help us be responsible with these gifts, using them wisely and to the advantage of others. Amen.

Secondly, the dialectic between the offertory and Lord's Supper promises a potential 'time of the question'. In this example, participants place mobile devices in the offertory receptacle which is brought to the Eucharistic table. At the Eucharistic table, mobile devices become part of the offering and are returned when participants receive the elements. This gesture also invokes the loss people often feel when parting with mobile devices. Participants become newly aware of technics as gift and responsibility.

One may ask: Why not just power down mobile devices as some plays, concerts, or other large events sometime request? Christian liturgy, modelled through general complexity, cannot, however, nostalgically pretend that the emerging technical epoch does not occupy background brain-time even when switched off. Christian liturgy, thus modelled, remains very aware of the technical environment: hoping to engage and transform technical epochal change through ritual practice, to elicit the otium of a 'time of the question'.

These are but two possibilities. What remains key is this: Christian liturgies should deal with the emerging technical epoch constructively. Although we have given two examples of how Christian liturgies may contribute to a general organology, much remains to be undertaken to pull the emerging technical epoch's generated pharmakon into the consistency of promising the future. If not, humans risk perceptual blindness somewhere between hyper-activity and hyper-distraction.

In a now famous experiment, Simons and Chabris (1999) improvised on an earlier iteration by Neisser and Becklen (1975) to test perceptual blindness. To summarise: test subjects were asked to watch a video in which two groups one in black and another in white shirts - randomly passed a basketball. Test subjects where primed to count the amount of basketball passes between either the black or white shirt group. Whilst focussed on counting the assigned groups' passes a person with an umbrella, or alternatively in a gorilla suit, would walk in between the passers. The majority of test subjects did not see the umbrella carrier, nor the person suited as a gorilla.

This experiment highlights how hyper-attention also results in a hyper-distraction producing inattentional perceptual blindness. In conclusion, the present article attempted to show how Christian liturgy can help contribute to a 'time of the question': an otium assisting humans to once again see the digital ethical gorilla hidden amidst an attention distracting mist.

\section{Acknowledgements Competing interests}

The authors declare that they have no financial or personal relationships which may have inappropriately influenced them in writing this article.

\section{Authors' contributions}

C.C.d.T. and G.M.L. contributed equally to the writing of this article.

\section{References}

Cilliers, P., 1998, Complexity \& postmodernism: Understanding complex systems, Routledge, New York.

Cilliers, P., 2005, 'Complexity, deconstruction and relativism', Theory, Culture \& Society 22(5), 255-267. http://dx.doi.org/10.1177/0263276405058052

Cilliers, P., 2007, 'On the idea of a certain slowness: Stability, memory, hysterisis in complex systems', in C. Gershenson, D. Aerts \& B. Edmonds (eds.), Worldviews, science and us: philosophy and complexity, pp. 53-64, World Scientific Publishing, science and us: philosophy and complexity, pp. 53-64, World Scier
Singapore. http://dx.doi.org/10.1142/9789812707420_0004.

Cilliers, P., 2010, 'Difference, identity and complexity', Philosophy Today 54(1), 55-65. http://dx.doi.org/10.1007/978-90-481-9187-1_1

Cilliers, P. \& Nicolescu, B., 2012, 'Complexity and transdisciplinarity - Discontinuity, levels of reality and the hidden third', Futures 44, 711-718. http://dx.doi.org/10.1016/ j.futures.2012.04.001

Crowley, M., 2013, 'The artist and the Amateur, from misery to invention', in C. Howells \& G. Moore (eds.), Stiegler and technics, pp. 119-134, Edinburgh University Press, Edinburgh.

Derrida, J., 1994, Specters of marx: The state of the debt, the work of mourning, and the New International, transl. P. Kamuf, Routledge, New York.

Du Toit, C.C., 2014, 'New directions in urban spiritualities: Beyond zero-sum readings', Theology 117(4), 243-248. http://dx.doi.org/10.1177/0040571x14529729

Du Toit, C.C., 2015, 'Modelling Christian spirituality as transversal urban space', Pharos Journal of Theology 96, 1-19.

Füssel, S., 2005, Gutenberg and the impact of printing, D. Martin (ed.), Ashgate, Burlington.

Galleni, L., 2011, 'Teilhard de Chardin's Multicentric Model in science and theology A proposal for the Third Millenium', in J.F. Salmon \& J. Farina (eds.), The Legacy of Pierre Teilhard de Chardin, pp. 59-78, Paulist Press, New York.

Gladwell, M., 2004, 'The Terrazzo Jungle', The New Yorker, 15 March 2004, viewed 08 October 2015, from http://www.newyorker.com/magazine/2004/03/15/theterrazzo-jungle.

Goriunova, O., 2012, 'New media idiocy', Convergence: The International Journal of Research into New Media Technologies 19(2), 223-235. http://dx.doi.org/10.1177/ 1354856512457765

Harries, K., 1983, The Bavarian Rococo Church: Between faith and aestheticism, Yale University Press, New Haven.

Hugo, V., 2011, Notre Dame de Paris, Norph-Nop Editions.

Human, O. \& Cilliers, P., 2013, 'Towards an economy of complexity: Derrida, Morin and Bataille', Theory, Culture \& Society 30(5), 24-44. http://dx.doi.org/10.1177/ 0263276413484070

Ingalls, M.M., 2008, Awesome in this place: Sound, space, and identity in contemporary North American evangelical worship, University of Pennsylvania, Philadelphia.

Lanier, J., 2010, You are not a gadget: A Manifesto, Alfred A. Knopf, New York.

Lewis, M., 2013, 'Of a mythical philosophical anthropology: The transcendental and the empirical in technics and time', in C. Howells \& G. Moore (eds.), Stiegler and technics, pp. 53-68, Edinburgh University Press, Edinburgh.

Miner, H., 1956, 'Body Ritual among the Nacirema', American Anthropologist 58 503-507. http://dx.doi.org/10.1525/aa.1956.58.3.02a00080

Morin, E., 2007, 'Restricted complexity, general complexity', in C. Gershenson, D. Aerts \& B. Edmonds (eds.), Worldviews, science and us: Philosophy and complexity, pp. 5-29, World Scientific Publishing, Singapore. http://dx.doi.org/10.1142/ 9789812707420_0002

Neisser, U. \& Becklen, R., 1975, 'Selective looking: Attending to visually specified events', Cognitive Psychology 7, 480-494. http://dx.doi.org/10.1016/0010-0285(75)90019-5

Ross, D., 2013, 'Pharmacology and critique after deconstruction', in C. Howells \& G. Moore (eds.), Stiegler and technics, Edinburgh University Press, Edinburgh.

Simons, D.J. \& Chabris, C.F., 1999, 'Gorillas in our midst: Sustained inattentional blindness for dynamic events, Perception 28(9), 1059-1074. http://dx.doi. org/10.1068/p281059

Smith, J.K.A., 2009, Desiring the kingdom: Worship, worldview, and cultural formation, Baker Academic, Grand Rapids.

Spadaro, A., 2014, Cybertheology: Thinking Christianity in the era of the Internet, transl. M. Way, Fordham University Press, New York. 
Stiegler, B., 1998, Technics and time: The fault of Prometheus, transl. R. Beardsworth \& George Collins, Stanford University Press, Stanford.

Stiegler, B., 2010, Taking care of youth and the generations, transl. S. Barker, Stanford University Press, Stanford.

Stiegler, B., 2013, What makes life worth living: On pharmacology, transl. D. Ross, Polity, Cambridge.

Stiegler, B., 2014a, Symbolic misery: Vol. 1. the hyperindustrial epoch, transl. B. Norman, Polity, Cambridge.

Stiegler, B., 2014b, The lost spirit of capitalism: Disbelief and discredit, Vol. 3, transl. D. Ross, Polity, Cambridge.

Stiegler, B., 2015, 'System and technics', H. Finidori (interviewer), Spanda Journal 1 75-81.
Van Huyssteen, J.W., 1997, Essays in postfoundationalist theology, Eerdmans, Grand Rapids.

Van Huyssteen, J.W., 1999, The shaping of rationality: Toward interdisciplinarity in theology and science, Eerdmans, Grand Rapids.

Versfeld, M., 2004, Food for thought: A philosopher's cookbook, Double Storey Books, Cape Town.

Virilio, P., 2005, Negative horizon, Continuum, New York.

Virilio, P., 2007, The original accident, Polity, Cambridge.

Woermann, M. \& Cilliers, P., 2012, 'The ethics of complexity and the complexity of ethics', South African Journal of Philosophy 31(2), 403-419.

Žižek, S. \& Gunjević, B., 2012, God in pain: Inversions of apocalypse, Seven Story Press, New York. 